\title{
Effect of Environmental Conditions and Morphometric Parameters on Surface Water Temperature in Polish Lakes
}

\author{
Mariusz Ptak ${ }^{1, *(D)}$, Mariusz Sojka ${ }^{2}$, Adam Choiński ${ }^{1}$ and Bogumił Nowak ${ }^{3}$ \\ 1 Department of Hydrology and Water Management, Adam Mickiewicz University, Krygowskiego 10, \\ 61-680 Poznań, Poland; choinski@amu.edu.pl \\ 2 Institute of Land Improvement, Environmental Development and Geodesy, \\ Poznań University of Life Sciences, Piątkowska 94, 60-649 Poznań, Poland; masojka@up.poznan.pl \\ 3 Institute of Meteorology and Water Management, National Research Institute, Podleśna 61, 01-673 \\ Warszawa, Poland; rugosa@op.pl \\ * Correspondence: marp114@wp.pl
}

Received: 9 March 2018; Accepted: 26 April 2018; Published: 29 April 2018

\begin{abstract}
The study evaluated the effect of environmental conditions and morphometric parameters on lake water temperature changes. The analysis was carried out on the basis of 14 lakes located in northern Poland. The assessment was based on the daily water and air temperatures from 1972 to 2016. It took into account the location of lakes (latitude, longitude, altitude) morphometric parameters (surface area, maximum and mean depth, volume), hydrological processes (rate of water exchange, course of ice phenomena), and trophic status (water transparency) as factors that can modify lake water temperature changes. Direction and rate of air and water temperature changes were analysed by means of Mann-Kendall's and Sen's tests. Cluster analysis (CA) was applied to group lakes characterised by similar water temperature changes. The effect of climatic and non-climatic parameters on a lake's water temperature was assessed on the basis of principal component analysis (PCA). Water temperatures in the lakes in the years 1972-2016 were characterised by a higher rate of increase of $0.43{ }^{\circ} \mathrm{C} \cdot \mathrm{dec}^{-1}$ than the air temperature decrease of $0.34{ }^{\circ} \mathrm{C} \cdot \mathrm{dec}^{-1}$. The analysis showed a faster rate of heating of waters in western Poland. This can be explained by shorter duration of ice cover. Moreover, the changes of water temperature were affected by other factors, including the location of the lakes, their morphometric parameters, wind speed, water transparency and water exchange time.
\end{abstract}

Keywords: climate change; global warming; water temperature; lakes; ice cover; wind; morphometry; Central Europe

\section{Introduction}

The effects of global warming are generally visible in all processes occurring on Earth [1-5]. Due to this, it currently constitutes one of the most serious problems of humanity. The issue should be analysed in two ways: on the one hand employing measures aimed at the reduction of greenhouse gases, and on the other hand searching for possibilities to minimise the environmental transformation caused by climatic changes. The former requires international arrangements (where achieving a consensus is difficult due to the complex geopolitical situation). The latter refers to particular local or individual components of the environment.

In the case of lakes and the observed changes in the thermal regime, the scale of the process should be determined as accurately as possible, as well as the primary factors modifying the effect of climate. Such an approach not only provides an accurate image of transformations, but also provides 
information that will support appropriate measures. The issue of water temperature fluctuations in lakes is frequently discussed, among other reasons, due to the key importance of the parameter in the course of all processes and phenomena occurring in those ecosystems. Numerous studies concern the physical-chemical [6,7], biological [8,9], and hydrological aspects $[10,11]$. Considering the elementary importance of temperature for the functioning of lakes, issues related to the consequences of global warming are of high importance. Due to the close dependency between air and water temperature [12], the process of heating of surface waters is treated as an indicator of climatic transformations [13]. The rate of increase in water temperature in particular cases can be higher than that of air temperature [14]. This situation reflects the complexity of processes determining the thermal regime of lakes.

The response of water temperature in lakes to observed climatic changes is variable, and it can be non-uniform even over a relatively small area. Magee and $\mathrm{Wu}$ [15] analysed changes in temperature in the epilimnion layer of three lakes in the vicinity of Madison. In spite of the climatic uniformity of the region, the tendency of water temperature increase was variable as a result of morphometric parameters of the analysed lakes. Winslow et al. [16], analysing 142 lakes in the United States, determined that the response of small and large lakes to the effect of climate is different. Another issue is the effect of local conditions of the location of lakes. Their effect on water temperature and the closely related ice cover on lakes is particularly evident in mountainous areas $[17,18]$. An increase in water temperature in lakes is a commonly observed situation [19-22]. Sometimes, however, the effect of local conditions can cause a different response. Tanentzap et al. [23] described such a situation in the case of thermal conditions of Clearwater Lake in the suburbs of the city of Sudbury (Canada), resulting from a forest growing back after local reductions in $\mathrm{SO}_{2}$ emissions. Luoto and Nevalainen [24] evidenced divergent trends of water temperature changes in the case of three lakes located in the Alps, suggesting among other factors that the characteristics of the catchment and stratification play an important role in the determination of the thermal regime of the lake.

In the case of northern Poland, where more than 7000 natural lakes are located [25], the process of changes in their water temperature is particularly important, not only due to the course of environmental processes, but also in economic terms, among others in reference to the possibilities of deterioration of water quality or changes in resources. Pursuant to current findings [26], surface water temperature in Polish lakes is increasing at a high rate. Higher water temperature and, consequently, an increase in evaporation [27], will contribute to an existing deficit in Poland which in terms of water resources per inhabitant is comparable with countries of the dry zone [28].

Current studies concerning lake water temperature in Poland [29-31] have not considered the effect of many factors (climatic, morphometric, hydrological) on its course and changes in a complex way. In order to fill this gap and investigate the most current conditions concerning the thermal regime of lakes in Poland, the objectives of this study were as follows:

(i) to determine the directions and value of changes in surface water temperature in Polish lakes;

(ii) to assess similarities and differences in thermal conditions of lakes;

(iii) to identify climatic and non-climatic factors determining water temperature in lakes as well as the rate and direction of their changes.

\section{Materials and Methods}

\subsection{Study Site Description}

Lakes in Poland constitute $0.9 \%$ of its total surface area, although their distribution is uneven. More than $95 \%$ of them are located in the northern part of the country as a result of the range of the last Scandinavian glaciation (Figure 1). The genesis of the majority of them refers to the processes of erosion and accumulation accompanying the presence of the ice sheet. The lakes of different origins analysed in the paper include those located in the direct vicinity of the Baltic Sea and constituting its former bays [32]. The morphometric parameters of the lakes are presented in Table 1. 
Table 1. Parameters of the analysed lakes (numbering in accordance with Figure 1).

\begin{tabular}{|c|c|c|c|c|c|c|c|c|c|c|c|c|c|}
\hline No. & Lake & $\begin{array}{l}\text { Meteorological } \\
\text { Station }\end{array}$ & $\begin{array}{l}\text { Latitude } \\
\text { North } \\
\text { (Lake) }\end{array}$ & $\begin{array}{l}\text { Longitude } \\
\text { East } \\
\text { (Lake) }\end{array}$ & $\begin{array}{l}\text { Depth } \\
\text { Max }[\mathrm{m}]\end{array}$ & $\begin{array}{l}\text { Depth } \\
\text { Mean } \\
{[\mathrm{m}]}\end{array}$ & $\begin{array}{l}\text { Area } \\
\text { [ha] }\end{array}$ & $\begin{array}{l}\text { Altitude } \\
\text { [m a.s.l.] }\end{array}$ & $\begin{array}{c}\text { Transparency } \\
\text { Secchi }[\mathrm{m}]\end{array}$ & $\begin{array}{c}\text { Average } \\
\text { Duration of } \\
\text { Ice Cover } \\
\text { [days] }\end{array}$ & $\begin{array}{l}\text { \% Water Exchange in } \\
\text { a Year (Retention } \\
\text { Time) }\end{array}$ & $\begin{array}{l}\text { Volume } \\
\text { [thou. } \mathrm{m}^{3} \text { ] }\end{array}$ & $\begin{array}{l}\text { Average Wind } \\
\text { Speed }\left[\mathrm{m} \cdot \mathrm{s}^{1}\right]\end{array}$ \\
\hline 1 & Sławskie & Zielona Góra (A) & 51.89 & 16.02 & 12.3 & 5.2 & 822.5 & 56.9 & 1.1 & 55 & 1.6 & $42,664.8$ & 3.2 \\
\hline 2 & Lubie & Piła (B) & 53.45 & 15.91 & 46.2 & 11.6 & 1487.5 & 95.5 & 2.7 & 55 & 1.0 & $169,880.5$ & 2.8 \\
\hline 3 & Gardno & Łeba (C) & 54.71 & 17.39 & 2.6 & 1.3 & 2337.5 & 0.3 & 0.7 & 55 & 0.2 & $30,950.5$ & 4.9 \\
\hline 4 & Łebsko & Łeba (C) & 54.65 & 17.10 & 6.3 & 1.6 & 7020 & 0.3 & 0.6 & 55 & 0.4 & $117,521.0$ & 4.9 \\
\hline 5 & Sepoleńskie & Chojnice (D) & 53.46 & 17.51 & 10.9 & 4.8 & 157.5 & 112.8 & 1.2 & 65 & 0.6 & 7501.6 & 3.7 \\
\hline 6 & Charzykowskie & Chojnice (D) & 53.77 & 17.50 & 30.5 & 9.8 & 1336 & 120 & 2.1 & 65 & 0.6 & $134,533.2$ & 3.7 \\
\hline 7 & Wdzydze & Chojnice (D) & 53.98 & 17.91 & 69.5 & 15.5 & 1417 & 134 & 2.9 & 75 & 1.3 & 220,800 & 3.7 \\
\hline 8 & $\begin{array}{l}\text { Raduńskie } \\
\text { Górne }\end{array}$ & Chojnice (D) & 54.24 & 17.98 & 43 & 15.5 & 362.5 & 161.6 & 4.1 & 75 & 2.6 & $60,158.7$ & 3.7 \\
\hline 9 & Bachotek & Toruń (E) & 53.30 & 19.47 & 24.3 & 7.2 & 215 & 70.8 & 3.6 & 75 & 0.5 & $15,394.2$ & 2.7 \\
\hline 10 & Jeziorak & Olsztyn (F) & 53.72 & 19.62 & 12.9 & 4.1 & 3152.5 & 99.2 & 0.8 & 85 & 3.2 & $141,594.2$ & 2.9 \\
\hline 11 & Mikołajskie & Mikołajki (G) & 53.77 & 21.60 & 25.9 & 11.2 & 424 & 115.7 & 1.3 & 85 & 0.2 & $55,739.7$ & 3.0 \\
\hline 12 & Selmęt Wielki & Mikołajki (G) & 53.83 & 22.48 & 21.9 & 7.8 & 1207.5 & 120.7 & 1.5 & 85 & 0.3 & 9963.9 & 3.0 \\
\hline 13 & Hańcza & Suwałki $(\mathrm{H})$ & 54.27 & 22.81 & 106.1 & 38.7 & 291.5 & 227.3 & 5.2 & 85 & 12.0 & $120,364.1$ & 3.8 \\
\hline 14 & Studzieniczne & Suwałki (H) & 53.87 & 23.12 & 30.5 & 8.7 & 244 & 123.4 & 2.7 & 95 & 3.6 & $22,073.6$ & 3.8 \\
\hline
\end{tabular}




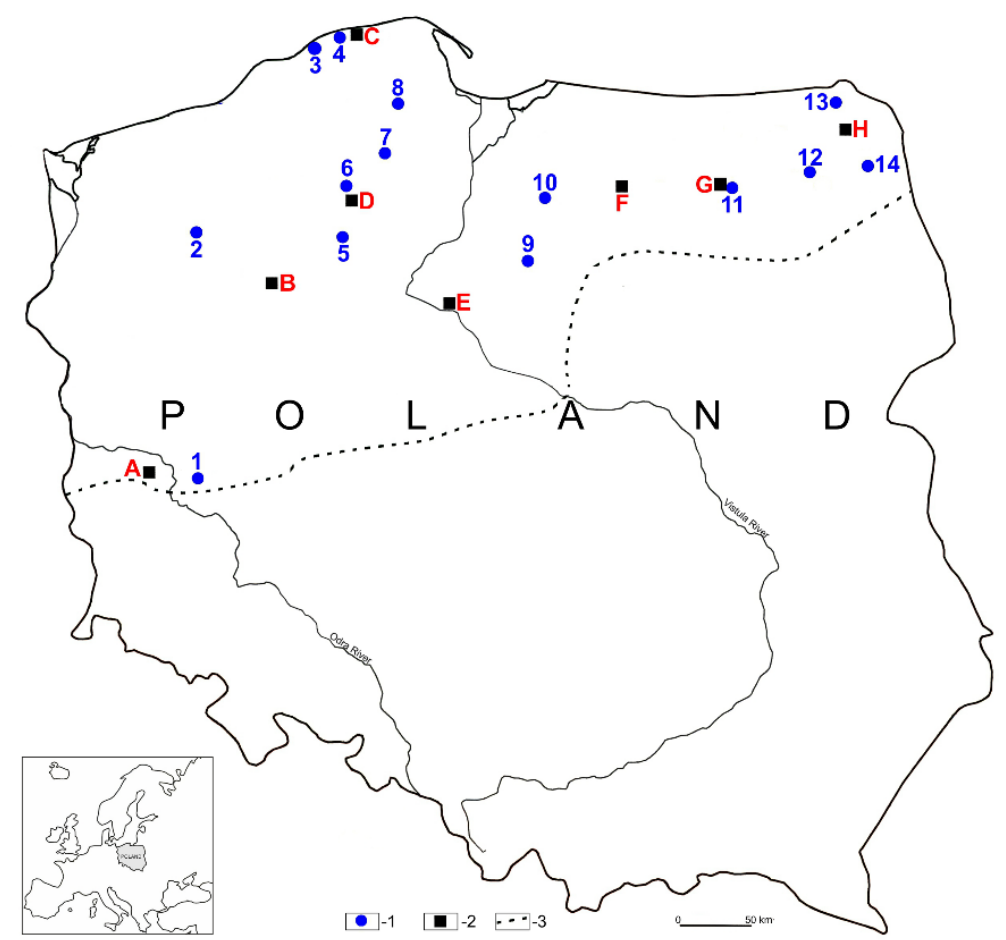

Figure 1. Location of study objects. 1-lakes, 2-meteorological station, 3-range of the Scandinavian glaciation.

\subsection{Materials}

The study evaluated daily water temperatures in 14 lakes in Poland (Figure 1). The measurements were taken by the Institute of Meteorology and Water Management-National Research Institute (IMGW-PIB) in the years 1972-2016, pointwise at a depth of $0.4 \mathrm{~m}$ under the water surface at 6.00 UTC. The data were compiled for the hydrological year beginning on 1 November and ending on 31 October of the following year. Moreover, data of IMGW-PIB provided the applied daily air temperatures and average wind speed values for eight meteorological stations (Figure 1).

Based on a literature review, a group of factors potentially modifying the effect of climatic factors was designated. As shown by analyses performed to date $[13,33,34]$, the spectrum of factors determining thermal conditions occurring in lakes is broad. In reference to the aforementioned studies and according to the availability of data, the following parameters were used in the study: those related to the location of lakes (latitude and longitude, altitude), their morphometric parameters (surface area, maximum and average depth, volume), hydrological processes (rate of water exchange, course of ice phenomena), and trophic status (water transparency [35]) (Table 1).

\subsection{Statistical Analysis}

Based on daily water temperatures, average monthly and annual temperatures were calculated. This provided the basis for the calculation of average values (AWT) and medians (MWT) of water temperature for the analysed period 1972-2016. Based on average annual water temperatures, the amplitude of temperature fluctuations (AWTA) and variability coefficient (AWTV) were determined. The values of AWT, MWT, AWTA and AWTV were calculated in order to provide the general characteristics of thermal conditions of water in the analysed lakes. At the same time, the AWT value was the input parameter for trend analysis. In the case of air temperatures, values of average annual temperatures and average temperature for the period 1972-2016 were calculated (AAT). Dependencies between average annual water temperatures in lakes and average annual 
air temperatures from the nearest meteorological station were determined by means of Pearson's correlation coefficient.

The objective of the next analysis was to assess the magnitude and direction of changes in water temperatures in both monthly and annual periods. For this purpose, two statistical tests were used: the Mann-Kendall test and Sen's slope estimate. The existence of a monotonic increasing or decreasing trend was performed by means of a non-parametric Mann-Kendall test (MK) [36]. The Mann-Kendall test is a non-parametric test for monotonic trends. The Mann-Kendall statistics show whether a trend exists and whether the trend is positive or negative. The analysis of significance of trends of average monthly and average annual lake water temperatures was performed for four different levels of significance $\mathrm{p}_{\alpha}: 0.1,0.05,0.01$, and 0.001 . At the second stage, the value of changes in average monthly and average annual water temperatures in the lakes (AWTT) (trend line slope) was determined based on the non-parametric Sen's test [37]. Sen's method was also applied to determine the direction coefficient of the trend line, which shows changes in monthly and annual air temperatures (AATT). In Mann-Kendall's and Sen's methods, gaps in data are acceptable, and the analysed data series do not have to have a specific distribution. Moreover, Sen's method is resistant to the occurrence of outliers in the data series [38]. For the purpose of comparison of the rate of changes in average annual water temperatures in lakes and changes in air temperatures, an analysis of significance of differences between AWTT and AATT was performed. Trend values are given in degrees Celsius per decade $\left({ }^{\circ} \mathrm{C} \cdot \mathrm{dec}^{-1}\right)$. The assessment was based on the non-parametric Kruskal-Wallis (KW) test. One-way analysis of variance for Kruskal-Wallis ranks was employed for the verification of the hypothesis of significance of differences between medians AWTT and AATT.

For the purpose of selecting lakes characterised by similar thermal conditions and value of changes in water temperatures, cluster analysis (CA) was applied. The assessment of similarities and differences between lakes in terms of AWT and AWTT employed Ward's method. The applied similarity measure was square Euclidean distance. The Ward method for the estimation of distance between clusters employs the variance analysis approach, aiming at the minimisation of total square deviations within clusters. As a result of the application of the CA method, dendrograms were obtained, presenting the hierarchical structure of the studied lakes by decreasing similarity between AWT and AWTT. The cluster analysis (CA) method was also applied for grouping months characterised by similar changes in temperatures over the analysed years. The grouping was performed based on monthly values of water temperature trends. To establish the groups in the CA method, the cut-off criterion of $66 \%$ was used. The proposed cut-off criterion is slightly higher than the cut-off criterion of $60 \%$ proposed by Obolewski et al. [39]. Additionally, to distinguish subgroups, the cut-off value of $25 \%$ was proposed. Accepting the value at the proposed level enabled a relatively homogeneous subgroup to be separated without creating a large number of small subgroups.

The determination of the effect of climatic and non-climatic factors on water temperature in lakes described by the parameters AWT, MWT, AWTT, AWTA and AWTV involved principal component analysis (PCA). The climatic factors adopted in the analysis included AAT, AATT and wind speed (WS). Non-climatic factors included the location of the lakes (latitude, longitude, altitude), morphometric parameters (area, volume, mean depth-AD, maximum depth-MD), location in the hydrographic system (time of water retention in lakes calculated as the ratio of lake volume and average outflow), trophic status (water transparency-Secchi visibility), and average duration of occurrence of ice cover in lakes. The PCA analysis permitted the exploration of the structure and general patterns in dependencies between thermal parameters and climatic and non-climatic factors. The PCA analysis permits the presentation of data in new (orthogonal) spaces defined by principal components (PC). The number of significant principal components was selected based on a Kaiser criterion of eigenvalues higher than 1 . The correlation between principal components and analysed data was classified according to the values $>0.75,0.75-0.50$, and $0.50-0.30$ proposed by Liu et al. [40] as strong, moderate and weak, respectively. 


\section{Results}

\subsection{Lake Water Temperature}

Average water temperatures (AWT) in the years 1972-2016 in the studied lakes varied from $8.6{ }^{\circ} \mathrm{C}$ in Lake Hańcza to $10.9^{\circ} \mathrm{C}$ in Lake Sławskie at a mean value of $9.8^{\circ} \mathrm{C}$. Distribution of daily water temperatures in the lakes is shown in Figure 2. Distributions of water temperatures in lakes showed a right-skewed distribution. Average water temperature values (AWT) were higher than values of median water temperatures (MWT), which varied from $6.4^{\circ} \mathrm{C}$ to $10.5^{\circ} \mathrm{C}$. Average water temperature amplitudes (AWTA) in particular years varied from $21.9^{\circ} \mathrm{C}$ in Lake Gardno to $25.2{ }^{\circ} \mathrm{C}$ in Lake Jeziorak. The highest variability of average annual water temperatures was observed in Lake Hańcza (the coefficient of skewness was 83\%), and the lowest in Lake Sławskie (the coefficient of skewness was $68 \%$ ). The average value of the variability coefficient of average annual water temperatures was $73 \%$.

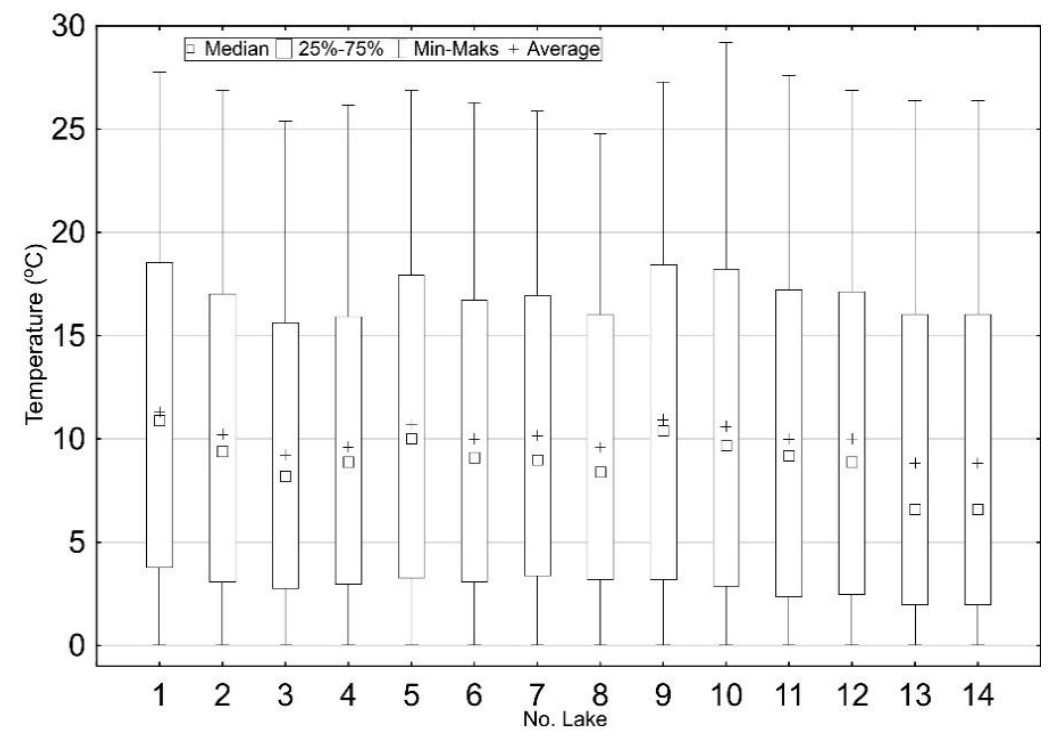

Figure 2. Daily lake water temperature distribution.

In terms of similarity of water temperatures in lakes, two main groups were identified, including smaller subgroups. The first group includes four lakes identified by numbers 1, 5, 9 and 10, where the average water temperature is $10.5^{\circ} \mathrm{C}$ (Figure 3). Lakes from this group are located in different climatic regions, and their common feature is the lowest of the analysed (apart from coastal lakes) average depth. The remaining lakes constitute the second group with three subgroups. The first subgroup includes lakes with numbers 2, 6, 7, 8, 12, 11 and 14. Similarly as in the first group, the lakes are located in different parts of the study area, and their characteristic feature is also depth, determining the development of thermal stratification in the summer. Water temperature in the lakes averages $9.6{ }^{\circ} \mathrm{C}$. The second subgroup includes lakes located in the coastal zone. They are identified by numbers 3 and 4 , and are subject to the direct effect of intrusion of marine water. The last group includes Lake Hańcza with number 13. It is the deepest lake in this part of Europe and, therefore, a considerable part of its water is isolated from the direct impact of external factors. According to Skowron [41], the hypolimnion layer covers $89 \mathrm{~m}$, constituting more than $75 \%$ of the lake's volume. 


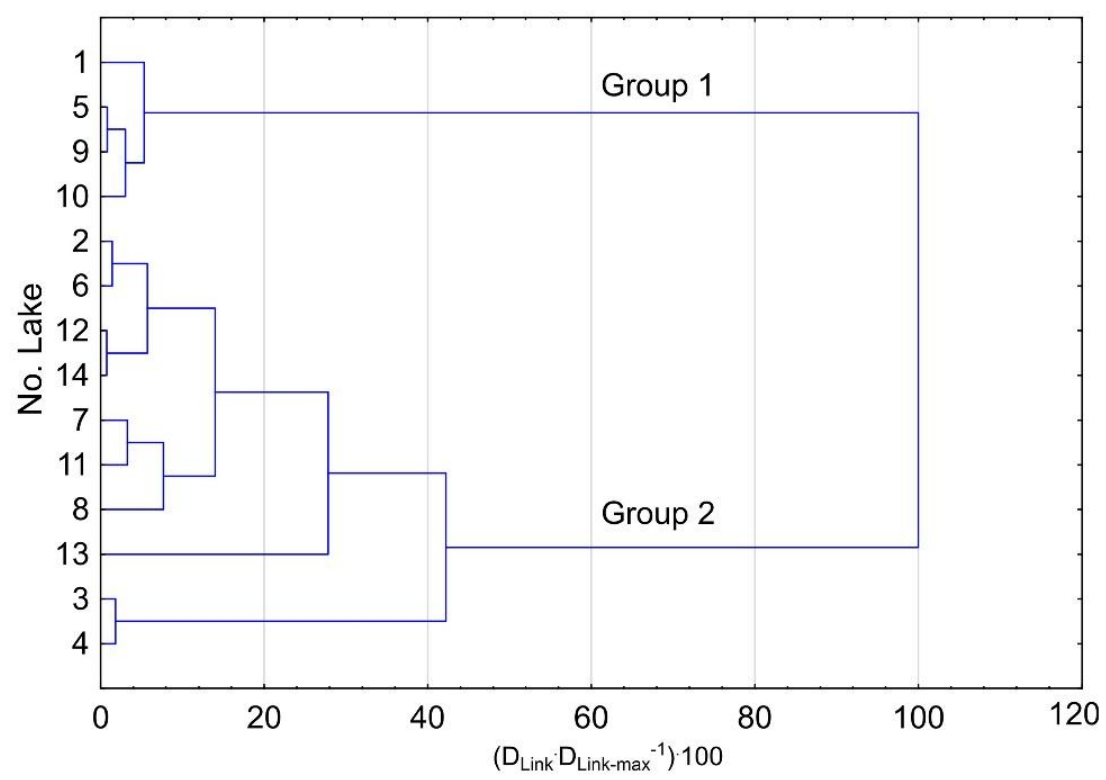

Figure 3. Grouping lakes by average annual water temperatures.

\subsection{Water Temperature Trends in Lakes}

The analysis showed an increase in average annual surface water temperatures in the years 1972-2016. The change of average temperature in the analysed lakes was $0.43^{\circ} \mathrm{C} \cdot \mathrm{dec}^{-1}$. The largest increase in water temperatures was observed in Lake Lubie $\left(0.64{ }^{\circ} \mathrm{C} \cdot \mathrm{dec}^{-1}\right)$, and the lowest in Lake Hańcza $\left(0.32{ }^{\circ} \mathrm{C} \cdot \mathrm{dec}^{-1}\right)$. A more detailed analysis of the water temperature in individual lakes showed that significant changes occurred in most months of the year. Significant trends in water temperature changes for all analysed lakes were observed in April, May, June, July and August. In the case of Lakes Gardno, Łebsko, Sepoleńskie, and Jeziorak, water temperature trends in January, February, March and December were generally not statistically significant (Table 2). Lakes Łebsko and Gardno are coastal lakes. In winter, intrusions of seawater are observed, which modifies the impact of atmospheric factors on the temperature of the water in these lakes [42]. The remaining cases are Lakes Jeziorak and Sępoleńskie, adjacent to cities (Iława and Sepólno Krajeńskie). These lakes are exposed to the outflow of water from adjacent urban areas, which can modify the direct impact of atmospheric factors. In the case of Lake Hańcza, no significant trends were observed in water temperature changes in January, September, October, November, and December. The observed situation can be explained by vertical movements of water and its supply to the near-surface layer from the hypolimnion zone with considerable thickness. 
Table 2. Results of the analysis of annual and monthly trends of water temperatures in lakes.

\begin{tabular}{|c|c|c|c|c|c|c|c|c|c|c|c|c|c|c|}
\hline No. & Lake & Nov. & Dec. & Jan. & Feb. & Mar. & Apr. & May & Jun. & Jul. & Aug. & Sep. & Oct. & Year \\
\hline 1 & Sławskie & $* * *$ & * & $*$ & & $*$ & $* * *$ & $* * *$ & $* *$ & $* * *$ & $* * *$ & $* * *$ & $* * *$ & $* * *$ \\
\hline 2 & Lubie & $* * *$ & $* *$ & $* * *$ & $* * *$ & $* * *$ & $* * *$ & $* * *$ & $* * *$ & $* * *$ & $* * *$ & $* * *$ & $* * *$ & $* * *$ \\
\hline 3 & Gardno & $* *$ & & & & & $* * *$ & $* *$ & $*$ & $*$ & $* *$ & $* *$ & + & $* * *$ \\
\hline 4 & Łebsko & + & & & & & $* * *$ & $* * *$ & * & $* *$ & $* *$ & $* * *$ & & $* * *$ \\
\hline 5 & Sepoleńskie & $* * *$ & * & & & & $* *$ & $* *$ & $* *$ & * & $* * *$ & $* * *$ & $* * *$ & $* * *$ \\
\hline 6 & Charzykowskie & $* *$ & $* *$ & * & $* *$ & $* *$ & $* * *$ & $* * *$ & $*$ & $* *$ & $* *$ & $* *$ & $*$ & $* * *$ \\
\hline 7 & Wdzydze & $* *$ & * & * & * & + & $* * *$ & $* * *$ & $* * *$ & $* *$ & $* * *$ & $* * *$ & $* *$ & $* * *$ \\
\hline 8 & $\begin{array}{l}\text { Raduńskie } \\
\text { Górne }\end{array}$ & $* * *$ & ** & $* *$ & $* *$ & $* *$ & $* * *$ & $* * *$ & $* * *$ & $*$ & $* *$ & $* *$ & & $* * *$ \\
\hline 9 & Bachotek & $* * *$ & $* *$ & * & $* * *$ & + & $* *$ & $* * *$ & $* * *$ & $* *$ & $* * *$ & $* * *$ & $* * *$ & $* * *$ \\
\hline 10 & Jeziorak & $* *$ & & & & & $*$ & $* *$ & $*$ & ** & $* * *$ & $* * *$ & $* *$ & $* * *$ \\
\hline 11 & Mikołajskie & $* *$ & $*$ & & * & + & $* *$ & $* *$ & $*$ & $* *$ & $* * *$ & $* *$ & $*$ & $* * *$ \\
\hline 12 & Selmęt Wielki & $* * *$ & $* * *$ & ** & * & * & $* * *$ & $* * *$ & $* *$ & $* *$ & $* * *$ & $* *$ & $* *$ & $* * *$ \\
\hline 13 & Hańcza & & & & + & + & $* * *$ & $* * *$ & $* * *$ & * & $*$ & & & $* * *$ \\
\hline 14 & Studzieniczne & $* * *$ & * & * & $* *$ & * & $* *$ & $* *$ & $*$ & $* *$ & $* * *$ & ** & * & $* * *$ \\
\hline
\end{tabular}

The highest rate of increase in water temperature was recorded in May (mean $-0.74{ }^{\circ} \mathrm{C} \cdot \mathrm{dec}^{-1}$; median $-0.71{ }^{\circ} \mathrm{C} \cdot \mathrm{dec}^{-1}$ ), and the lowest in January (mean $-0.16^{\circ} \mathrm{C} \cdot \mathrm{dec}^{-1}$; median $-0.19^{\circ} \mathrm{C} \cdot \mathrm{dec}^{-1}$ ) and February (mean $-0.16^{\circ} \mathrm{C} \cdot \mathrm{dec}^{-1}$; median $-0.18^{\circ} \mathrm{C} \cdot \mathrm{dec}^{-1}$ ) (Figure 4a). The highest variability of trends of changes in water temperature between the lakes was observed in November, December, May, June and September. The average difference was approximately $0.59^{\circ} \mathrm{C} \cdot \mathrm{dec}^{-1}$. Lower variability of temperature trends between the analysed lakes occurred in January, February, and August-averaging $0.29^{\circ} \mathrm{C} \cdot \mathrm{dec}^{-1}$. The performed cluster analysis permitted the division of months into two groups based on the similarity of trends of water temperature. The first group included eight months in which the average water temperature increase was $0.51{ }^{\circ} \mathrm{C} \cdot \mathrm{dec}^{-1}$ (Figure $4 \mathrm{~b}$ ). The second group included December, January, February and March, when lower water temperatures were recorded, at a level of $0.20{ }^{\circ} \mathrm{C} \cdot \mathrm{dec}^{-1}$. In the first group, two subgroups were identified: one comprising September, October and November, and one comprising April, May, June, July and August. In September, October and November, changes in temperature trends were smaller. They were not statistically significant in any of the lakes.
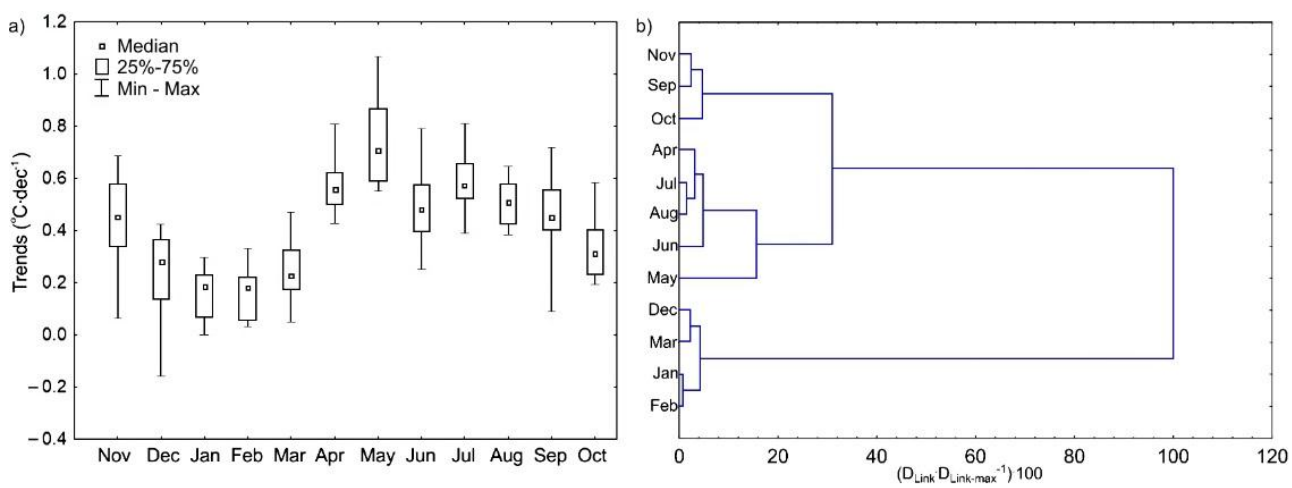

Figure 4. Monthly trends of water temperature in lakes (a) and results of grouping months based on trends by means of the cluster analysis (CA) method (b).

Similarly as in the case of the average water temperature, the procedure of grouping lakes by similarity of trends of water temperature was performed (Figure 5). The procedure showed dependencies more complex than in the case of the analysis of average water temperature. The first group included seven lakes (identified by numbers 1, 2, 6, 7, 8, 9 and 12) where the temperature increase over the years $1972-2016$ varied from 0.46 to $0.64{ }^{\circ} \mathrm{C} \cdot \mathrm{dec}^{-1}$ at the average value of $0.50{ }^{\circ} \mathrm{C} \cdot \mathrm{dec}^{-1}$. The second group included the remaining lakes where temperature increases were smaller and 
varied from 0.32 to $0.41{ }^{\circ} \mathrm{C} \cdot \mathrm{dec}^{-1}$ at an average of $0.36{ }^{\circ} \mathrm{C} \cdot \mathrm{dec}^{-1}$. Lakes deviating from the defined groups were Lake Lubie in the first group, and Lake Hańcza in the second group. The analysis of morphometric parameters of the lakes and hydrological conditions within groups A and B (excluding Lakes Hańcza and Lubie from the analysis) showed that lakes included in group A usually had a smaller surface area, higher $\mathrm{AD}, \mathrm{MD}$, and water transparency determined by means of the Secchi disc.

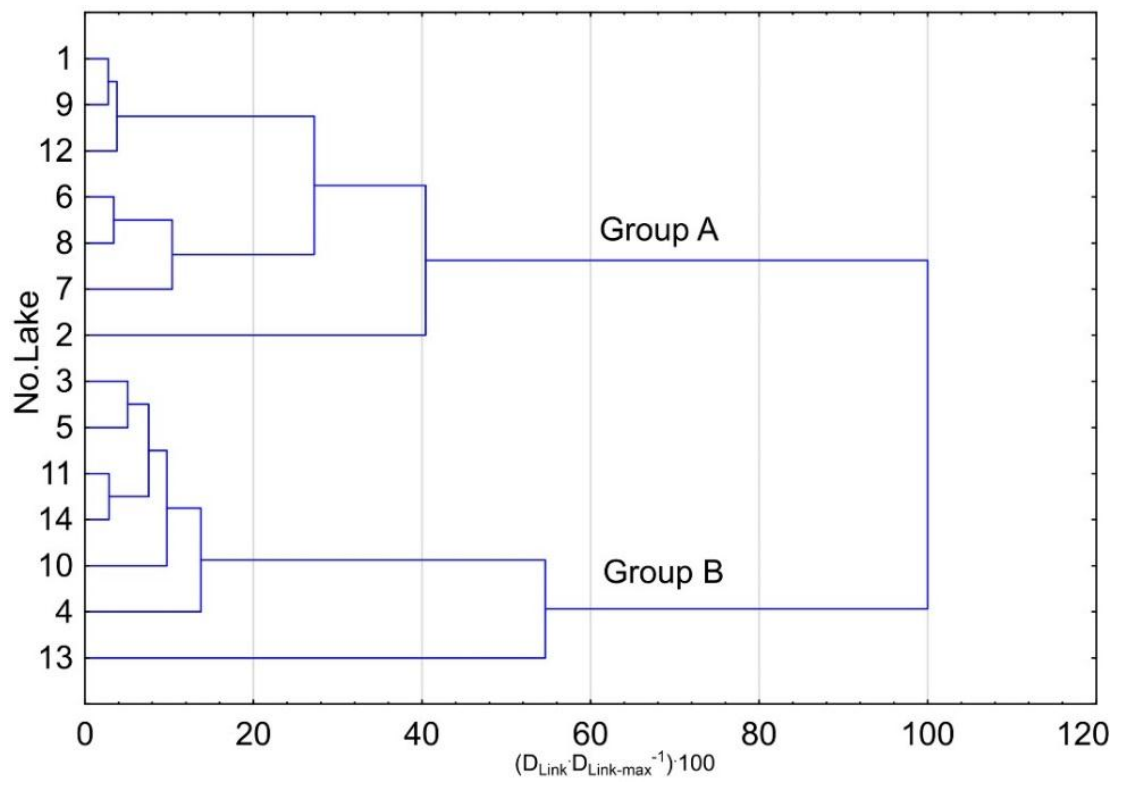

Figure 5. Grouping of lakes based on temperature trends.

\subsection{Conditions of Distribution of Water Temperatures and Trends}

Air temperature is of key importance for the thermal conditions of lakes [43,44]. Due to this, changes in water temperature largely depend on the distribution of the latter. The determined characteristics of air temperature for 8 meteorological stations (Figure 1) showed that the average annual value was $7.9^{\circ} \mathrm{C}$ and was variable in geographic terms. For the Zielona Góra station (western Poland), the average annual temperature in the analysed multiannual period was $8.9^{\circ} \mathrm{C}$, and for the Suwałki station (eastern Poland) it was $6.6^{\circ} \mathrm{C}$. The total average rate of increase for all stations was approximately $0.34{ }^{\circ} \mathrm{C} \cdot \mathrm{dec}^{-1}$. The analysis of monthly trends of air temperatures showed that in December, January, February, March and October, trends of temperatures were not statistically significant. The largest changes in air temperatures occurred in April and August (Table 3).

Table 3. Significance of trends of air temperature.

\begin{tabular}{cccccccccccccc}
\hline Meteorological Station & Nov. & Dec. & Jan. & Feb. & Mar. & Apr. & May & Jun. & Jul. & Aug. & Sep. & Oct. & Year \\
\hline Zielona Góra & $*$ & & & & & $* * *$ & $* *$ & $*$ & $*$ & $* *$ & $*$ & & $* * *$ \\
Suwałki & $*$ & & & & & $* * *$ & & $*$ & $* * *$ & $* *$ & $*$ & & $* *$ \\
Chojnice & $*$ & & & & & $* * *$ & + & $*$ & $*$ & $* *$ & $*$ & & $* * *$ \\
Olsztyn & + & & & & & $* * *$ & & $*$ & $* *$ & $* * *$ & $*$ & & $* *$ \\
Pila & $*$ & & & & & $* * *$ & $*$ & $*$ & $*$ & $* *$ & $*$ & & $* * *$ \\
Mikołajki & + & & & & & $* * *$ & & $*$ & $* *$ & $* *$ & $*$ & & $* *$ \\
Łeba & $*$ & & & & & $* * *$ & $*$ & $*$ & $*$ & $* * *$ & $* *$ & & $* *$ \\
Torun & $*$ & & & & & $* * *$ & + & $*$ & $* *$ & $* *$ & $*$ & & $* *$ \\
\hline
\end{tabular}

${ }^{* * *}$ trend at $\alpha=0.001$ level of significance. ${ }^{* *}$ trend at $\alpha=0.01$ level of significance. ${ }^{*}$ trend at $\alpha=0.05$ level of significance. + trend at $\alpha=0.1$ level of significance.

Figure 6 presents the course of the average annual water and air temperature (a) and distribution of trends of water temperature in lakes and air (b). The course of average annual water temperature reveals its evident warming, closely corresponding with air temperature. It should also be emphasised 
that it is higher, as mentioned earlier. The analysis of differences in annual trends of water temperatures and air temperatures showed that they are statistically significant at a level of $\alpha=0.05$. Water temperatures in lakes in the years 1972-2016 were characterised by a larger increase averaging $0.43{ }^{\circ} \mathrm{C} \cdot \mathrm{dec}^{-1}$, and air temperatures at a level of $0.34^{\circ} \mathrm{C} \cdot \mathrm{dec}^{-1}$. Lower variability was observed in the case of air temperatures at the analysed meteorological stations than trends of water temperatures between particular lakes (Figure 6b).
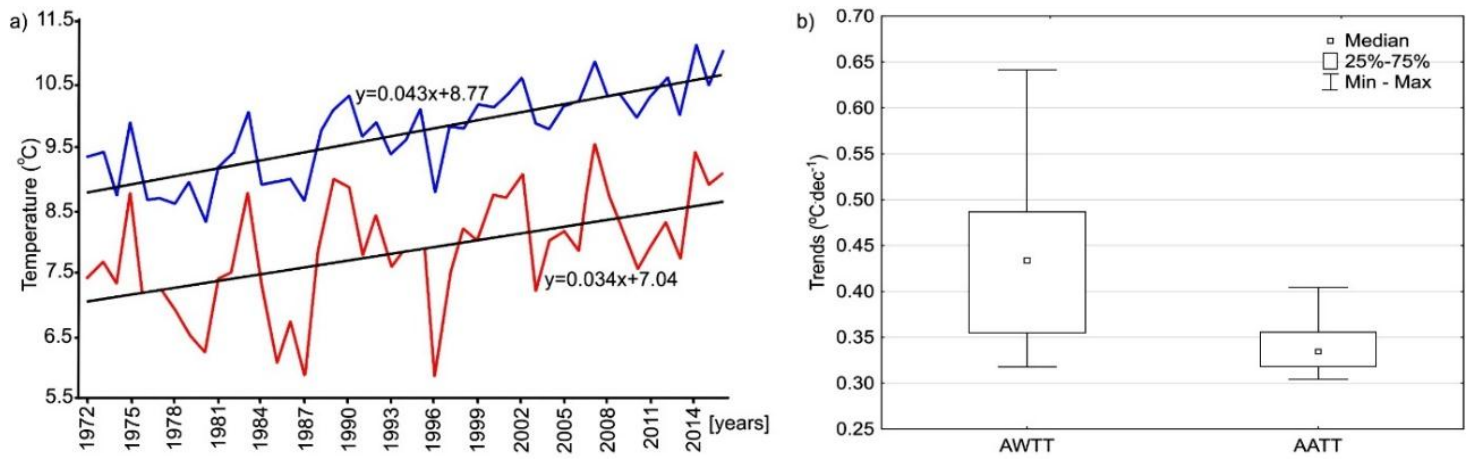

Figure 6. Course of the average annual water temperature (for all lakes—blue colour), and course of the average annual air temperature (for all stations-red colour) (a), and significance of differences in trends of average annual water temperatures (AWTT) and monthly and annual air temperatures (AATT) (b) in the years 1972-2016.

High dependencies between water temperature in the analysed lakes and air temperature evidenced earlier are confirmed by Table 4.

Table 4. Correlations between average air temperatures and average water temperatures (relations of lakes and meteorological stations located at the shortest distance).

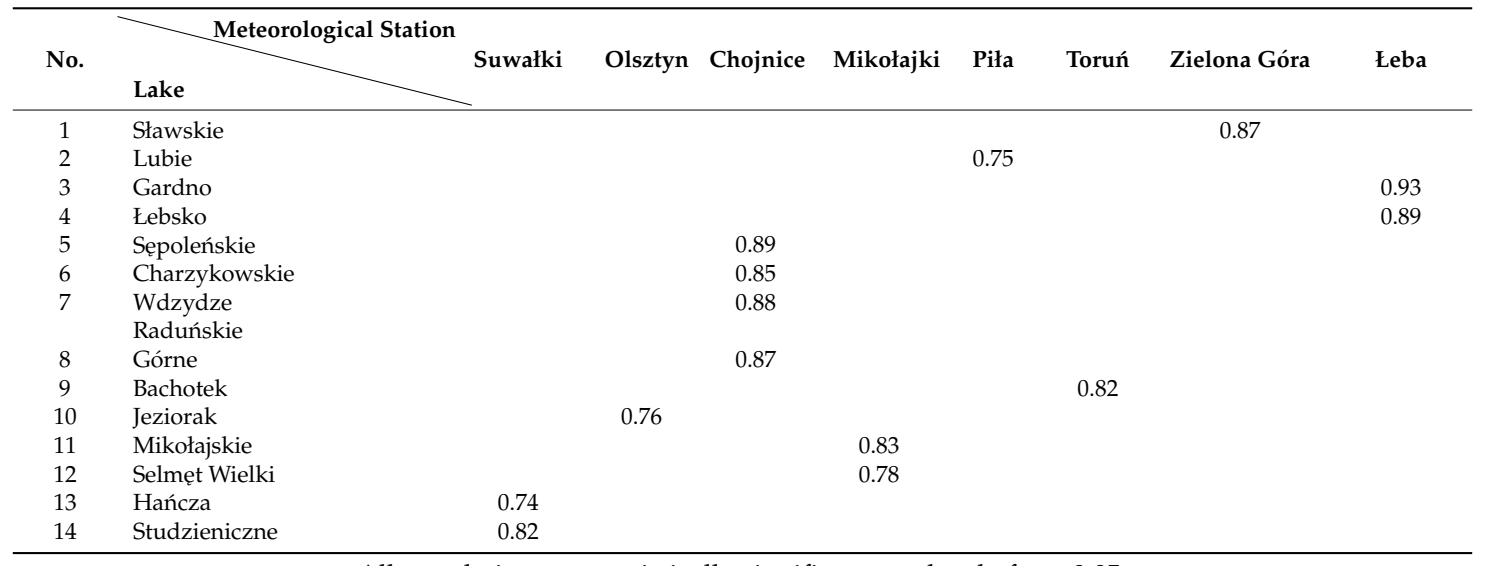

All correlations are statistically significant at a level of $\alpha=0.05$

Correlations between water temperature and air temperature were high. At the same time, variability of correlations is observed even in the case of lakes located near each other. This reflects the role of the individual parameters of the lakes in the reception of climatic signals. The effect of a variable group of climatic factors on the course of lake water temperature in Poland was explained by means of the PCA analysis (Figure 7). The PCA analysis permitted the identification of two principal components, PC1 and PC2, with eigenvalues higher than 1. The principal components explain in total $84.1 \%$ of internal structure of data. The remaining percentage can be related to e.g., groundwater alimentation of lakes, the role of which in water temperature distribution is emphasised by, among 
others, Safaie et al. [45]. Unfortunately, in the case of Poland, no relevant studies are currently available in this scope.

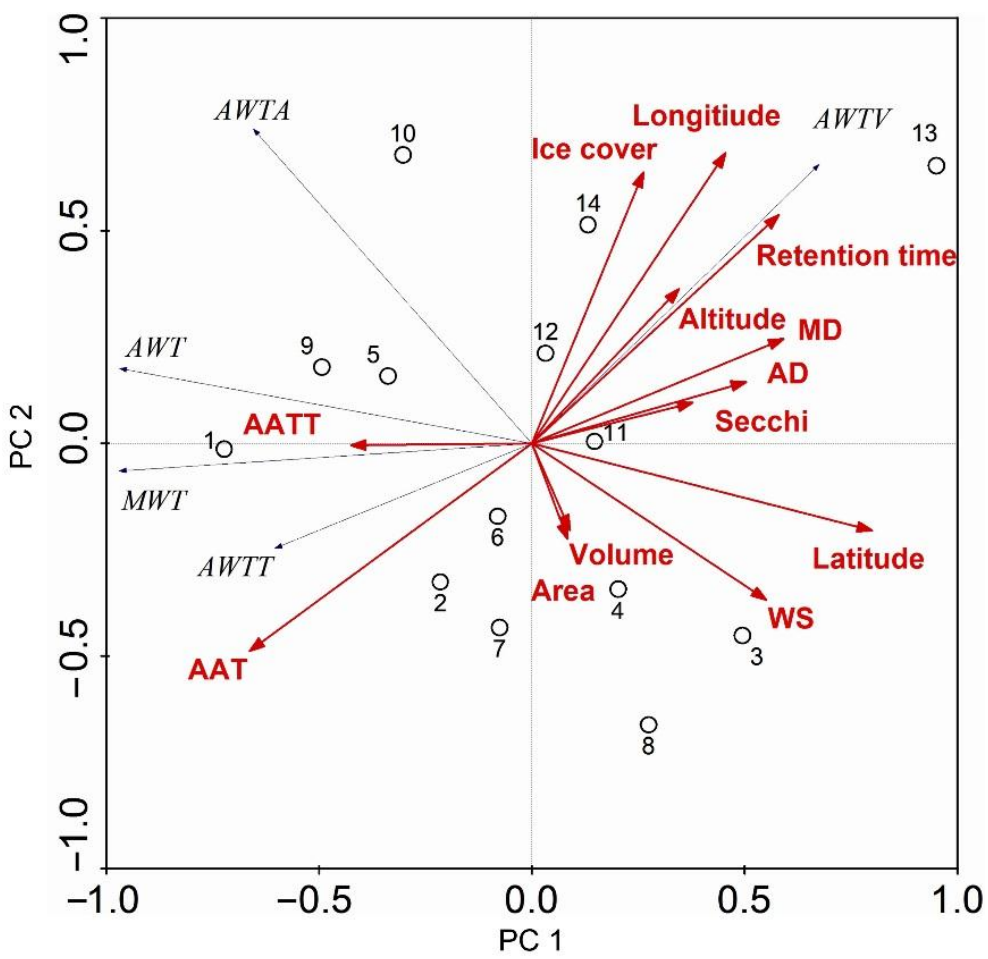

Figure 7. Results of principal component analysis (PCA) between thermal parameters of waters in the lakes and climatic and non-climatic parameters.

\section{Discussion and Conclusions}

The analyses permitted the determination of the direction and value of changes in surface water temperature in Polish lakes, similarities and differences in thermal conditions occurring in the lakes, and the effect of climatic and non-climatic factors determining the rate and direction of changes in water temperature. The adopted method allowed for the implementation of the predefined study objectives.

The first principal component PC1 (vertical axis in Figure 7) was positively correlated with AWTV on an average level, negatively with AWT and MWT on a strong level, and with AWTT and AWTA on an average level. PC2 (vertical axis in Figure 7) was positively correlated only with AWTA and AWTV on an average level. Among explanatory variables, PC1 was positively correlated with latitude (on a strong level) and $\mathrm{AD}, \mathrm{MD}$, retention time, and wind speed (on an average level), and negatively only with AAT (on an average level). PC2 was positively correlated on an average level only with longitude, ice cover and retention time.

Considering the correlations occurring between the thermal conditions of waters in lakes and the remaining climatic and non-climatic parameters, it is worth emphasising the occurrence of a negative correlation between AWTT and retention time, MD and longitude. This means that a higher increase in water temperature over the analysed years occurred in lakes with shorter retention time with lower maximum depths. Note also that higher increases in water temperature occur in the lakes of western Poland. Lakes in which higher AWTT values were observed were characterised by lower variability of annual temperatures over the analysed years. A detailed explanation of the results obtained is presented below in reference to particular factors affecting water temperature.

The key element in this context is air temperature (compare Table 4) with distribution depending on the location of a particular region. Depending on the latitude, longitude and altitude, certain patterns should be expected in the distribution of air temperature, and consequently lake water 
temperature. In the case of the Northern Hemisphere, it will generally decrease with a shift northwards. Analysing latitude in reference to Europe, it will decrease towards the east, where continental air masses are prevalent. Such a situation is quite evident in the analysed area with features of transitional climate [46] with prevalence of features of humid and warmer climate in the west of the country and colder in the east. This is consequently confirmed by average annual water temperatures in lakes, adopting quite a transparent pattern in terms of values with an east-west orientation.

Another element referring to environmental parameters is the height of lakes above sea level. It is most evident in mountainous areas, where a rapid increase in height affects the course of water temperature [47]. Although the analysed lakes are located in the lowland zone, the PCA analysis showed negative correlations of water temperature with height above sea level. The existing hypsometric differences reaching approximately $230 \mathrm{~m}$ are a result of the presence of postglacial landforms, e.g., the highest located lake (Hańcza) is located on the ridge of a terminal moraine, and the two lowest located lakes (Łebsko and Gardno) are located in the direct vicinity of the Baltic Sea.

Among the most serious threats to lakes are climatic changes [48]. This has been particularly evident since the second half of the 1980s, when a considerable increase in water temperature was observed. The situation in the case of lakes in Central Europe is explained by Woolway et al. [49], concluding that it is a response to a change in the climatic regime. In the context of air temperatures $[50,51]$, they will determine the transformation of their thermal conditions. The statement is confirmed by predictive estimations of changes in water temperature in lakes $[52,53]$. The increase in water temperature recorded in the analysed lakes was $0.42{ }^{\circ} \mathrm{C} \cdot \mathrm{dec}^{-1}$. The result corresponds with other similar research. The analysis of changes in lake water temperatures in Latvia in the years 1946-2002 showed positive tendencies. Over the last 15 years, water temperature was higher by $0.4-0.8{ }^{\circ} \mathrm{C}$ in comparison to the preceding period [54]. An increase in lake water temperatures has occured in other parts of Europe and the world. In northern Europe, in the case of the largest lake in Europe, Lake Ladoga, Naumenko et al. [55] determined that the average increase in surface water temperature in the years $1956-2003$ was $0.5-0.7^{\circ} \mathrm{C} \cdot \mathrm{dec}^{-1}$. In the case of Lake Albufera in southern Spain, water temperature has increased by $0.34^{\circ} \mathrm{C} \cdot \mathrm{dec}^{-1}$ since 1950 [56]. Mooij et al. [57] determined an increase in lake water temperature in The Netherlands in the years $1961-2006$ of $0.4{ }^{\circ} \mathrm{C} \cdot \mathrm{dec}^{-1}$. In the case of Lake Baikal, an increase in temperature at a level of $0.2{ }^{\circ} \mathrm{C} \cdot \mathrm{dec}^{-1}$ has been recorded over the last 60 years. In the summer period, surface water temperature in this deepest lake in the world rapidly increased at an average rate of $0.38{ }^{\circ} \mathrm{C} \cdot \mathrm{dec}^{-1}$ [58]. Schneider and Hook [59], analysing trends of changes in water temperature in more than 100 lakes all over the world, determined its increase, among other places, in the area of the Black Sea averaging $0.4-0.5^{\circ} \mathrm{C} \cdot \mathrm{dec}^{-1}$, in northern China and Mongolia $0.5-0.7{ }^{\circ} \mathrm{C} \cdot \mathrm{dec}^{-1}$, in North America, in the area of the Great American Lakes $0.5-0.6{ }^{\circ} \mathrm{C} \cdot \mathrm{dec}^{-1}$, and in the south-eastern part of the United States approximately $0.7^{\circ} \mathrm{C} \cdot \mathrm{dec}^{-1}$.

According to the data presented above, an increase in water temperature in lakes is common, and the scale depends on a number of elements with regional character or particular parameters of lakes. In the case of lakes of the moderate zone, the key role for the course of thermal conditions is played by the presence of ice cover [41]. The negative dependency between the duration of ice cover and water temperature (Figure 7) suggests that a decrease (reduction) in the former is accompanied by an increase (warming) in the latter. In the case of Poland in spatial terms, ice cover is subject to faster destruction in the western part of the country $[60,61]$. Considering the analysed lakes, the duration of ice cover is very variable, and in the case of Lake Lubie (in the western part of the area) it averages 55 days, while in the case of Lake Studzieniczne (in the eastern part of the study area) it averages 96 days. Therefore, the faster the ice cover disappears, the faster thermal stratification develops, and the longer the time of warming of only part of the (near-surface) water. The important effect of earlier stratification on an increase in water temperature is pointed out by, among others, Piccolroaz et al. [62]. The PCA analysis results show that lakes in the western part of the country are characterised by a larger increase in water temperature. This corresponds with the fact of faster disappearance of ice cover in that area. The relations between a reduction of the ice season and increase in water 
temperature are in accordance with other studies of the same type. In the case of Lake Superior, Austin and Colman [63] determined that a reduction of the ice season contributes to earlier beginning of the stratification season $\left(0.5\right.$ days.year $\left.{ }^{-1}\right)$, which prolongs the period in which the lake is warmed in the summer months, leading to a higher trend in the course of water temperature in comparison to the trend of air temperature. In the case of lakes in the area of the Great Lakes (North America), Mishra et al. [64] determined that ice cover was largely correlated with heat accumulated during spring and summer. Therefore, earlier decomposition of ice cover can contribute to larger increases in water temperature than air temperature in the area of their occurrence. The cases analysed in this paper confirm the situation. It is worth remembering that the average rate of increase in lake water temperature in Poland and average increase in air temperature (the former was higher by $15 \%$ ) are $0.42{ }^{\circ} \mathrm{C} \cdot \mathrm{dec}^{-1}$ and $0.35{ }^{\circ} \mathrm{C} \cdot \mathrm{dec}^{-1}$, respectively. It should also be emphasised that trends of changes in both centres showed regional variability: in the case of Lake Lubie and the Piła meteorological station (west of the area) it was 0.63 and $0.36{ }^{\circ} \mathrm{C} \cdot \mathrm{dec}^{-1}$, respectively, and e.g., for Lake Studzieniczne and the Suwałki station (east of the area) it was 0.39 and $0.36{ }^{\circ} \mathrm{C} \cdot \mathrm{dec}^{-1}$. Moreover, as explained by Kintisch [65], due to the faster disappearance of ice cover, lakes that normally freeze in winter are warmed approximately twice as fast as lakes in which the process does not occur. Lakes in the area of the Great American Lakes or in northern Europe were warmed considerably faster than the world average, unlike in the case of e.g., lakes located in the south-eastern part of North America [14].

A factor important for the distribution of water temperature in a lake is wind action. The relations have been the subject of numerous studies [66-68]. Magee and Wu [15], conducting research on temperature conditions of lakes in the USA, evidenced that the distribution of water temperature in lakes is equally strongly (or sometimes even more strongly) determined by the effect of wind than air temperature. Results obtained in this study confirm the above findings (Figure 7). The correlation between the trend of water temperature and average wind speed was $-0.66(\alpha=0.05)$. This value was higher than the recorded correlation between the trend of average annual water temperature and trend of air temperature, $0.51(\alpha=0.05)$. The correlation results from the fact that in conditions of lower wind strength, there is lower wave formation and, as a consequence, a higher amount of heat is accumulated in the shallower water layer. In reference to this finding, Woolway et al. [69] evidenced that decreasing wind speeds increase the number of days of stratification in the case of Lake Võrtsjärv in Estonia.

With regard to the development and duration of thermal stratification (and therefore the possible effect of atmospheric factors on the entire water mass, or only its near-surface part), the number of water circulation cycles in a year plays an important role, and the mictic type of the lake depends on its depth [70]. In the case of the analysed lakes, it was determined that correlations between maximum and average depth and water temperature are negative. This confirms the role of the amount of water subject to the effect of external factors. In the case of shallow (polymictic) lakes, it is the entire water mass, and in the case of stratified lakes, deeper zones (through the thermocline) are isolated from such an impact.

Higher accumulation of heat in the shallow water layer is also related to another parameter, namely water transparency. The negative correlation (Figure 7) suggests that lower Secchi visibility is accompanied by an increase in water temperature. Lakes characterised by low transparency retain heat nearer the surface [71]. Half of the cases analysed in the study show water transparency not exceeding a depth of $1.5 \mathrm{~m}$. Therefore, absorption of solar radiation occurs in this layer, and in unfavourable conditions (too weak or lack of wind) strong heating occurs. In the case of Crystal Lake, Rose et al. [72] found a decrease in water transparency with a simultaneous increase in surface water temperature and cooling of near-bottom waters. Transparency in Sparkling Lake did not change, and its surface and near-bottom waters were heated. The situation suggests the complexity of relations between water transparency and temperature. This also results from other research referring to this issue [73-75].

In the case of lakes in Poland, the performed analysis revealed a significant correlation between time of water retention in the lake and its temperature. It suggests that a smaller volume of water subject to exchange in a year is accompanied by an increase in its temperature. The considerable effect 
of water exchange in the river-lake system on the temperature of lake waters has been emphasised by, among others, Vinnä et al. [76] and Ptak et al. [77]. Kainz et al. [78], analysing changes in water temperature and ice phenomena in Lake Lunz (Austria), found that a short retention time causes a more dynamic heat budget in comparison to lakes with longer retention times. All lakes analysed in the study have a flow-through character, but due to their morphometric parameters and size of rivers, the rate of water exchange is variable. In a situation when it occurs more slowly, it remains under the influence of factors causing its heating for a longer time (air temperature, transparency). In the conditions of relatively fast water exchange and outflow from the lake, it is not able to respond to the above factors equally fast. Valerio et al. [79], analysing the thermal dynamics of Lake Iseo (Italy), found that the inflow-outflow process causes removal of heat from the lake at an average level of $3.6 \times 10^{16} \mathrm{~J}$ in a year. In the case of the northern part of the study area, the variability of the thermal conditions of stagnant and flowing waters is reflected in the analysis of thermal conditions of five rivers performed in a similar scope (1971-2015). Ptak et al. [80] determined an increase in average water temperature for them of $0.28{ }^{\circ} \mathrm{C} \cdot \mathrm{dec}^{-1}$, compared to $0.42{ }^{\circ} \mathrm{C} \cdot \mathrm{dec}^{-1}$ recorded for the lakes analysed in this study.

In reference to the surface area of the lake, an increase in the parameter was found to contribute to a decrease in surface water temperature. This situation refers to the findings presented above, emphasising the role of depth of the epilimnion and wind in its shaping. A larger surface area of a lake determines a greater possibility of an effect of wind on the lake, and consequently on the depth of the wave base. Greater mixing in turn increases vertical flow of heat to waters in deeper zones of the lake, which translates into a decrease of water temperature in the near-surface layer [81]. The role of the lake surface in water mixing (and consequently heat transfer) is emphasised by Nõges et al. [82]. Results similar to those obtained in the present study were also reported by, among others, Magee and $\mathrm{Wu}[15]$.

The present findings are in agreement with the extensive research referring to the thermal conditions of lake waters. As emphasised above, it constitutes an elementary factor determining the general functioning of lake ecosystems. The determined thermal parameters of water permitted the presentation of the complexity of relations between different components affecting their course. The results presented in the paper reflect the variability of the distribution and changes in surface water temperature in Polish lakes. A regional division into the east and west of the country is generally demonstrated. Such a situation is largely determined by transitional climate features, between continental and sea air masses, the dominant effect of which is observed with respect to the above designations. The response of lakes to the effect of the primary climatic parameters is modified by local conditions and their individual features. In the times of global warming, observed at least over the last several decades, the key issue is the precise determination of responses of lake ecosystems to the process. In all of the analysed cases, water temperature showed an increasing tendency, but the scale of warming varied. In this context, it is important to identify factors differentiating the process. The importance of this knowledge is evidenced by the observed effects of current transformations in lakes [83-87]. According to numerous papers [88-91], further transformation of thermal conditions (and the accompanying processes) will take place in the future.

The introduction of specific technical solutions potentially slowing down the heating of lake waters seems unavoidable. The results obtained suggest that such a solution may be sought in the hydrotechnical regulation of water exchange in lakes, or spatial management of lake catchments, etc. These are obviously just theoretical conjectures requiring a separate detailed expert opinion for each lake (environmental, legal conditions, etc.), but offering hope for the ability to alleviate, to some extent, the negative effects of our own activity, observed as climate warming.

Author Contributions: Mariusz Ptak- initiator of the study subject, interpretation of the results, conducted the introduction, conducted the discussion and prepared the manuscript. Mariusz Sojka- performed statistical calculations and their analysis. Adam Choinski-conducted the discussion. Bogumił Nowak-compiled data.

Conflicts of Interest: The authors declare no conflict of interest. 


\section{References}

1. Sharan, A.M.; Pathak, M. Global warming and its effect on flow in Ganga River. Asian J. Water Environ. Pollut. 2013, 10, 117-122.

2. Elizbarashvili, E.S.; Elizbarashvili, M.E.; Kutaladze, N.B.; Elizbarashvili, S.E.; Chelidze, N.Z. Long-term changes in the number and temperature of hot days in Georgia under global warming. Russ. Meteorol. Hydrol. 2017, 42, 665-670. [CrossRef]

3. Karmalkar, A.V.; Bradley, R.S. Consequences of global warming of $1.5^{\circ} \mathrm{C}$ and $2{ }^{\circ} \mathrm{C}$ for regional temperature and precipitation changes in the contiguous United States. PLOS ONE 2017, 12, e0168697. [CrossRef] [PubMed]

4. Miserendino, M.L.; Brand, C.; Epele, L.B.; Di Prinzio, C.Y.; Omad, G.H.; Archangelsky, M.; Martínez, O.; Kutschker, A.M. Biotic diversity of benthic macroinvertebrates at contrasting glacier-fed systems in Patagonia Mountains: The role of environmental heterogeneity facing global warming. Sci. Total Environ. 2018, 622-623, 152-163. [CrossRef] [PubMed]

5. Xiu, P.; Chai, F.; Curchitser, E.N.; Castruccio, F.S. Future changes in coastal upwelling ecosystems with global warming: The case of the California Current System. Sci. Rep. 2018, 8, 2866. [CrossRef] [PubMed]

6. Bartosiewicz, M.; Laurion, I.; Clayer, F.; Maranger, R. Heat-wave effects on oxygen, nutrients, and phytoplankton can alter global warming potential of gases emitted from a small shallow lake. Environ. Sci. Technol. 2016, 50, 6267-6275. [CrossRef] [PubMed]

7. Yang, K.; Yu, Z.; Luo, Y.; Yang, Y.; Zhao, L.; Zhou, X. Spatial and temporal variations in the relationship between lake water surface temperatures and water quality-A case study of Dianchi Lake. Sci. Total Environ. 2018, 624, 859-871. [CrossRef] [PubMed]

8. Pełechata, A.; Pełechaty, M.; Pukacz, A. Winter temperature and shifts in phytoplankton assemblages in a small Chara-lake. Aquat. Bot. 2015, 124, 10-18. [CrossRef]

9. Haberman, J.; Haldna, M. How are spring zooplankton and autumn zooplankton influenced by water temperature in a polymictic lake? Proc. Est. Acad. Sci. 2017, 66, 264-278. [CrossRef]

10. Gronewold, A.D.; Stow, C.A. Water loss from the great lakes. Science 2014, 343, 1084-1085. [CrossRef] [PubMed]

11. Wan, W.; Li, H.; Xie, H.; Hong, Y.; Long, D.; Zhao, L.; Han, Z.; Cui, Y.; Liu, B.; Wang, C.; et al. A comprehensive data set of lake surface water temperature over the Tibetan Plateau derived from MODIS LST products 2001-2015. Sci. Data 2017, 4, 170095. [CrossRef] [PubMed]

12. Livingstone, D.M.; Padisak, J. Large-scale coherence in the response of Lake surface-water temperatures to synoptic-scale climate forcing during summer. Limnol. Oceanogr. 2007, 52, 896-902. [CrossRef]

13. Adrian, R.; O’Reilly, C.M.; Zagarese, H.; Baines, S.B.; Hessen, D.O.; Keller, W.; Livingstone, D.M.; Sommaruga, R.; Straile, D.; Van Donk, E.; et al. Lakes as sentinels of climate change. Limnol. Oceanogr. 2009, 54, 2283-2297. [CrossRef] [PubMed]

14. O’Reilly, C.M.; Sharma, S.; Gray, D.K.; Hampton, S.E.; Read, J.S.; Rowley, R.J.; Schneider, P.; Lenters, J.D.; McIntyre, P.B.; Kraemer, B.M.; et al. Rapid and highly variable warming of lake surface waters around the globe. Geophys. Res. Lett. 2015, 42, 10773-10781. [CrossRef]

15. Magee, M.R.; Wu, C.H. Response of water temperatures and stratification to changing climate in three lakes with different morphometry. Hydrol. Earth Syst. Sci. 2017, 21, 6253-6274. [CrossRef]

16. Winslow, L.A.; Read, J.S.; Hansen, G.J.A.; Hanson, P.C. Small lakes show muted climate change signal in deepwater temperatures. Geophys. Res. Lett. 2015, 42, 355-361. [CrossRef]

17. Choiński, A.; Ptak, M.; Strzelczak, A. Areal variation in ice cover thickness on Lake Morskie Oko (Tatra Mountains). Carpath. J. Earth Environ. Sci. 2013, 8, 97-102.

18. Novikmec, M.; Svitok, M.; Kočický, D.; Šporka, F.; Bitušík, P. Surface water temperature and ice cover of Tatra Mountains Lakes depend on altitude, topographic shading and bathymetry. Arct. Antarct. Alp. Res. 2013, 45, 77-87. [CrossRef]

19. Coats, R.; Perez-Losada, J.; Schladow, G.; Richards, R.; Goldman, C. The warming of Lake Tahoe. Clim. Chang. 2006, 76, 121-148. [CrossRef]

20. Katsev, S.; Aaberg, A.A.; Crowe, S.A.; Hecky, R.E. Recent warming of Lake Kivu. PLoS ONE 2014, 9, e109084. [CrossRef] [PubMed] 
21. Huang, L.; Wang, J.; Zhu, L.; Ju, J.; Daut, G. The warming of large lakes on the Tibetan plateau: Evidence from a lake model simulation of Nam Co., China, during 1979-2012. J. Geophys. Res. Atmos. 2017, 122. [CrossRef]

22. Ptak, M.; Wrzesiński, D.; Choiński, A. Long-term changes in the hydrological regime of high mountain lake Morskie Oko (Tatra Mountains, Central Europe). J. Hydrol. Hydromech. 2017, 65, 146-153. [CrossRef]

23. Tanentzap, A.J.; Yan, N.D.; Keller, B.; Girard, R.; Heneberry, J.; Gunn, J.M.; Hamilton, D.P.; Taylor, P.A. Cooling lakes while the world warms: Effects of forest regrowth and increased dissolved organic matter on the thermal regime of a temperate, urban lake. Limnol. Oceanogr. 2008, 53, 404-410.

24. Luoto, T.P.; Nevalainen, L. Long-term water temperature reconstructions from mountain lakes with different catchment and morphometric features. Sci. Rep. 2013, 3, 2488. [CrossRef] [PubMed]

25. Choiński, A. Katalog jezior Polski; Wydawnictwo Naukowe Uniwersytetu im. Adama Mickiewicza: Poznań, Poland, 2006.

26. Dąbrowski, M.; Marszelewski, W.; Skowron, R. The trends and dependencies between air and water temperatures in the lakes located in Northern Poland in the years 1961-2000. Hydrol. Earth Syst. Sci. 2004, 8, 79-87. [CrossRef]

27. Sima, S.; Ahmadalipour, A.; Tajrishy, M. Mapping surface temperature in a hyper-saline lake and investigating the effect of temperature distribution on the lake evaporation. Remote Sens. Environ. 2013, 136, 374-385. [CrossRef]

28. Kowalczak, P.; Farat, R.; Kepińska-Kasprzak, M.; Kuźnicka, M.; Mager, P. Hierarchy of Aerial Smallwater Retention Need; Materiały Badawcze, Seria: Gospodarka Wodna a Ochrona Wód, 19; IMGW: Warszawa, Poland, 1997.

29. Kowalska, A. Termika jezior północnej Polski. Czas. Geogr. 1972, 43, 371-385.

30. Skowron, R. Water Temperature of Lakes in North Poland as Index of Climate Change. In Przeobrażenia Stosunków Wodnych w Warunkach Zmieniającego Się Środowiska. Jankowski, A.T., Absalon, D., Machowski, R., Ruman, M., Eds.; Wydział Nauk o Ziemi Uniwersytetu Śląskiego: Sosonowic, 2009; pp. 255-268.

31. Ptak, M.; Choiński, A.; Piekarczyk, J.; Pryłowski, T. Application of Landsat satellite thermal images in the analysis of the temperature of Polish lakes. Pol. J. Environ. Stud. 2017, 26, 2159-2165. [CrossRef]

32. Choiński, A.; Ptak, M.; Strzelczak, A. Present-day evolution of coastal lakes based on the example of Jamno and Bukowo (the Southern Baltic coast). Oceanol. Hydrobiol. Stud. 2014, 43, 178-184. [CrossRef]

33. Becker, M.W.; Daw, A. Influence of lake morphology and clarity on water surface temperature as measured by EOS ASTER. Remote Sens. Environ. 2005, 99, 288-294. [CrossRef]

34. Torbick, N.; Ziniti, B.; Wu, S.; Linder, E. Spatiotemporal lake skin summer temperature trends in the northeast United States. Earth Interact. 2016, 20, 25. [CrossRef]

35. Marszelewski, W. Changes of the Biotic Conditions in the Lakes of North-East Poland; Nicolaus Copernicus University Scientific Publisher: Torun, Poland, 2005; p. 288.

36. Kendall, M.G.; Stuart, A. The Advanced Theory of Statistics, 3; Charles Griffin (Ltd.): London, UK, 1968.

37. Gilbert, R.O. Statistical Methods for Environmental Pollution Monitorin; Van Nostrand Reinhold Co.: New York, NY, USA, 1987; p. 320.

38. Salmi, T.; Määttä, A.; Anttila, P.; Ruoho-Airola, T.; Amnell, T. Detecting Trends of Annual Values of Atmospheric Pollutants by the Mann-Kendall Test and Sen's Slope Estimates-The Excel Template Application MAKESENS; Publications on Air Quality 31; Finnish Meteorological Institute: Helsinki, Finland, 2002; p. 35.

39. Obolewski, K.; Glińska-Lewczuk, K.; Strzelczak, A. Does hydrological connectivity determine the benthic macroinvertebrate structure in oxbow lakes? Ecohydrology 2015, 8, 1488-1502. [CrossRef]

40. Liu, C.W.; Lin, K.H.; Kuo, Y.M. Application of factor analysis in the assessment of groundwater quality in blackfoot disease in Taiwan. Sci. Total Environ. 2003, 313, 77-89. [CrossRef]

41. Skowron, R. The Differentiation and the Changeability of Chosen Elements of the Thermal Regime of Water in Lakes on Polish Lowland; Nicolaus Copernicus University Scientific Publisher: Torun, Poland, 2011; p. 346.

42. Girjatowicz, J.P. The relationships between water level in coastal lakes and sea water of Polish coast of Baltic Sea. Prz. Geofiz. 2008, 53, 141-153.

43. Wrzesiński, D.; Choiński, A.; Ptak, M. Effect of the North Atlantic Oscillation on the thermal characteristics of lakes in Poland. Acta Geophys. 2015, 63, 863-883. [CrossRef] 
44. Ptak, M.; Nowak, B. Variability of oxygen-thermal conditions in selected lakes in Poland. Ecol. Chem. Eng. S 2016, 23, 639-650. [CrossRef]

45. Safaie, A.; Litchman, E.; Phanikumar, M.S. Evaluating the role of groundwater on circulation and thermal structure in a deep inland lake. Adv. Water Resour. 2017, 108, 310-327. [CrossRef]

46. Woś, A. Climate of Poland in the Second Half of the 20th Century; Wydawnictwo Naukowe Uniwersytetu im. Adama Mickiewicza: Poznań, Poland, 2010.

47. Livingstone, D.M.; Lotter, A.F.; Walker, I.R. The decrease in summer surface water temperature with altitude in Swiss Alpine lakes: A comparison with air temperature lapse rates. Arct. Antarct. Alp. Res. 1999, 31, 341-352. [CrossRef]

48. Carpenter, S.R.; Stanley, E.H.; Vander Zanden, M.J. State of the world's freshwater ecosystems: Physical, chemical, and biological changes. Annu. Rev. Environ. Resour. 2011, 36, 75-99. [CrossRef]

49. Woolway, R.I.; Dokulil, M.T.; Marszelewski, W.; Schmid, M.; Bouffard, D. Warming of Central European lakes and their response to the 1980s climate regime shift. Clim. Chang. 2017, 42, 505-520. [CrossRef]

50. Kruzel, J.; Ziernicka-Wojtaszek, A. Diversity of air temperature in Poland in the years 1971-2010. J. Ecol. Eng. 2016, 17, 27-231. [CrossRef]

51. Tomczyk, A.M.; Bednorz, E. Heat waves in Central Europe and their circulation conditions. Int. J. Climatol. 2016, 36, 770-782. [CrossRef]

52. Danis, P.-A.; von Grafenstein, U.; Masson-Delmotte, V.; Planton, S.; Gerdeaux, D.; Moisselin, J.-M. Vulnerability of two European lakes in response to future climatic changes. Geophys. Res. Lett. 2004, 31, 163-183. [CrossRef]

53. Rao, Y.R.; Huang, A.; Schertzer, W.M.; Rouse, W.R. Modelling of physical processes and assessment of climate change impacts in great bear lake. Atmos. Ocean 2012, 50, 317-333. [CrossRef]

54. Apsite, E.; Elferts, D.; Zubaničs, A.; Latkovska, I. Long-term changes in hydrological regime of the lakes in Latvia. Hydrol. Res. 2014, 45, 308-321. [CrossRef]

55. Naumenko, M.A.; Guzivaty, V.V.; Karetnikov, S.G. Climatic trends of the water surface temperature in Lake Ladoga during ice-free periods. Dokl. Earth Sci. 2006, 409, 750-753. [CrossRef]

56. Jeppesen, E.; Mehner, T.; Winfield, I.J.; Kangur, K.; Sarvala, J.; Gerdeaux, D.; Rask, M.; Malmquist, H.J.; Holmgren, K.; Volta, P.; et al. Impacts of climate warming on the long-term dynamics of key fish species in 24 European lakes. Hydrobiologia 2012, 694, 1-39. [CrossRef]

57. Mooij, W.M.; De Senerpont Domis, L.N.; Hülsmann, S. The impact of climate warming on water temperature, timing of hatching and young-of-the-year growth of fish in shallow lakes in the Netherlands. J. Sea Res. 2008, 60, 32-43. [CrossRef]

58. Hampton, S.E.; Izmest'eva, L.R.; Moore, M.V.; Katz, S.L.; Dennis, B.; Silow, E.A. Sixty years of environmental change in the world's largest freshwater Lake-Lake Baikal, Siberia. Glob. Chang. Biol. 2008, 14, 1947-1958. [CrossRef]

59. Schneider, P.; Hook, S.J. Space observations of inland water bodies show rapid surface warming since 1985. Geophys. Res. Lett. 2010, 37, 208-217. [CrossRef]

60. Wrzesiński, D.; Choiński, A.; Ptak, M.; Skowron, R. Effect of the North Atlantic Oscillation on the pattern of lake ice phenology in Poland. Acta Geophys. 2015, 63, 1664-1684. [CrossRef]

61. Choiński, A.; Ptak, M.; Skowron, R.; Strzelczak, A. Changes in ice phenology on Polish lakes from 1961-2010 related to location and morphometry. Limnologica 2015, 53, 42-49. [CrossRef]

62. Piccolroaz, S.; Toffolon, M.; Majone, B. The role of stratification on lakes' thermal response: The case of Lake Superior. Water Resour. Res. 2015, 51, 7878-7894. [CrossRef]

63. Austin, J.A.; Colman, S.M. Lake Superior summer water temperatures are increasing more rapidly than regional temperatures: A positive ice-albedo feedback. Geophys. Res. Lett. 2007, 34, 125-141. [CrossRef]

64. Mishra, V.; Cherkauer, K.A.; Bowling, L.C. Changing thermal dynamics of lakes in the Great Lakes region: Role of ice cover feedbacks. Glob. Planet. Chang. 2011, 75, 155-172. [CrossRef]

65. Kintisch, E. Earth's lakes are warming faster than its air: First ever global survey reveals summer lake temperatures rising at an alarming rate. Science 2015, 350, 1449. [CrossRef] [PubMed]

66. Findikakis, A.N.; Law, A.W.K. Wind mixing in temperature simulations for lakes and reservoirs. J. Environ. Eng. 1999, 125, 420-428. [CrossRef]

67. Desai, A.R.; Austin, J.A.; Bennington, V.; McKinley, G.A. Stronger winds over a large lake in response to weakening air-to-lake temperature gradient. Nat. Geosci. 2009, 2, 855-858. [CrossRef] 
68. Kimura, N.; Wu, C.H.; Hoopes, J.A.; Tai, A. Diurnal dynamics in a small shallow lake under spatially nonuniform wind and weak stratification. J. Hydraul. Eng. 2016, 142, 04016047. [CrossRef]

69. Woolway, R.I.; Meinson, P.; Nõges, P.; Jones, I.D.; Laas, A. Atmospheric stilling leads to prolonged thermal stratification in a large shallow polymictic lake. Clim. Chang. 2017, 141, 759-773. [CrossRef]

70. Choiński, A. Limnologia fizyczna Polski; Wydawnictwo Naukowe Uniwersytetu im. Adama Mickiewicza: Poznań, Poland, 2007.

71. Read, J.S.; Rose, K.C. Physical responses of small temperate lakes to variation in dissolved organic carbon concentrations. Limnol. Oceanogr. 2013, 58, 921-931. [CrossRef]

72. Rose, K.C.; Winslow, L.A.; Read, J.S.; Hansen, G.J.A. Climate-induced warming of lakes can be either amplified or suppressed by trends in water clarity. Limnol. Oceanogr. Lett. 2016, 1, 44-53. [CrossRef]

73. Xenopoulos, M.A.; Schindler, D.W. The environmental control of near-surface thermoclines in boreal lakes. Ecosystems 2001, 4, 699-707. [CrossRef]

74. Flaim, G.; Eccel, E.; Zeileis, A.; Toller, G.; Cerasino, L.; Obertegger, U. Effects of re-oligotrophication and climate change on lake thermal structure. Freshw. Biol. 2016, 61, 1802-1814. [CrossRef]

75. Richardson, D.C.; Melles, S.J.; Pilla, R.M.; Hetherington, A.L.; Knoll, L.B.; Williamson, C.E.; Kraemer, B.M.; Jackson, J.R.; Long, E.C.; Moore, K.; et al. Transparency, geomorphology and mixing regime explain variability in trends in lake temperature and stratification across Northeastern North America (1975-2014). Water 2017, 9, 442. [CrossRef]

76. Vinnä, L.R.; Wüest, A.; Zappa, M.; Fink, G.; Bouffard, D. Tributaries affect the thermal response of lakes to climate change. Hydrol. Earth Syst. Sci. 2018, 22, 31-51. [CrossRef]

77. Ptak, M.; Tomczyk, A.M.; Wrzesiński, D. Effect of teleconnection patterns on changes in water temperature in Polish lakes. Atmosphere 2018, 9, 1-17.

78. Kainz, M.J.; Ptacnik, R.; Rasconi, S.; Hager, H.H. Irregular changes in lake surface water temperature and ice cover in subalpine Lake Lunz, Austria. Inland Waters 2017, 7, 27-33. [CrossRef]

79. Valerio, G.; Pilotti, M.; Barontini, S.; Leoni, B. Sensitivity of the multiannual thermal dynamics of a deep pre-alpine lake to climatic change. Hydrol. Process. 2015, 29, 767-779. [CrossRef]

80. Ptak, M.; Choiński, A.; Kirviel, J. Long-term water temperature fluctuations in coastal rivers (Southern Baltic) in Poland. Bull. Geogr. Phys. Geogr. Ser. 2016, 11, 35-42. [CrossRef]

81. Boehrer, B.; Schultze, M. Stratification of lakes. Rev. Geophys. 2008, 46, RG000210. [CrossRef]

82. Nõges, P.; Nõges, T.; Ghiani, M.; Paracchini, B.; Pinto Grande, J.; Sena, F. Morphometry and trophic state modify the thermal response of lakes to meteorological forcing. Hydrobiologia 2011, 667, 241-254. [CrossRef]

83. Goyer, K.; Bertolo, A.; Pépino, M.; Magnan, P. Effects of lake warming on behavioural thermoregulatory tactics in a cold-water stenothermic fish. PLoS ONE 2014, 9, e92514. [CrossRef] [PubMed]

84. Baranov, V.; Lewandowski, J.; Krause, S. Bioturbation enhances the aerobic respiration of lake sediments in warming lakes. Biol. Lett. 2016, 12, 20160448. [CrossRef] [PubMed]

85. Izmest'eva, L.R.; Moore, M.V.; Hampton, S.E.; Ferwerda, C.J.; Gray, D.K.; Woo, K.H.; Pislegina, H.V.; Krashchuk, L.S.; Shimaraeva, S.V.; Silow, E.A. Lake-wide physical and biological trends associated with warming in Lake Baikal. J. Gt. Lakes Res. 2016, 42, 6-17. [CrossRef]

86. Przytulska, A.; Bartosiewicz, M.; Vincent, W.F. Increased risk of cyanobacterial blooms in northern high-latitude lakes through climate warming and phosphorus enrichment. Freshw. Biol. 2017, 62, 1986-1996. [CrossRef]

87. Hovel, R.A.; Thorson, J.T.; Carter, J.L.; Quinn, T.P. Within-lake habitat heterogeneity mediates community response to warming trends. Ecology 2017, 98, 2333-2342. [CrossRef] [PubMed]

88. Lepori, F. ; Roberts; J.J. Past and future warming of a deep European lake (Lake Lugano): What are the climatic drivers? J. Gt. Lakes Res. 2015, 41, 973-981. [CrossRef]

89. Van Zuiden, T.M.; Chen, M.M.; Stefanoff, S.; Lopez, L.; Sharma, S. Projected impacts of climate change on three freshwater fishes and potential novel competitive interactions. Divers. Distrib. 2016, 22, 603-614. [CrossRef] 
90. Bucak, T.; Trolle, D.; Tavşanoğlu, Ü.N.; Çakıroğlu, A.İ.; Özen, A.; Jeppesen, E.; Beklioğlu, M. Modeling the effects of climatic and land use changes on phytoplankton and water quality of the largest Turkish freshwater lake: Lake Beyşehir. Sci. Total Environ. 2018, 621, 802-816. [CrossRef] [PubMed]

91. Ladwig, R.; Furusato, E.; Kirillin, G.; Hinkelmann, R.; Hupfer, M. Climate change demands adaptive management of urban lakes: Model-based assessment of management scenarios for Lake Tegel (Berlin, Germany). Water 2018, 10, 186. [CrossRef] 